\title{
PROGRAM GASTIZI 1000 DALAM MENINGKATKAN KAPASITAS KADER POSYANDU
}

(Program GASTIZI 1000 for increasing capacity of posyandu cadres)

\author{
Rachma Purwanti ${ }^{*}$ \\ ${ }^{1}$ Departemen Ilmu Gizi, Fakultas Kedokteran, Universitas Diponegoro, Semarang, Indonesia. \\ E-mail: rachmapurwanti@fk.undip.ac.id
}

\begin{abstract}
ABSTRAK
Kader Posyandu merupakan penggerak utama Upaya Kesehatan Bersumberdaya Masyarakat (UKBM). Program "Cegah Stunting dengan Perbaikan Gizi pada 1000 HPK (GASTIZI 1000)" bertujuan untuk meningkatkan kapasitas dari kader Posyandu di Desa Ngarap-arap. Penelitian bertujuan untuk menganalisis efektifitas Program GASTIZI 1000 dalam meningkatkan kapasitas kader posyandu. Penelitian berdesain quasi experimental, dengan rancangan one group pre test-post test design. Penelitian dilakukan selama bulan Juli Agustus 2018. Topik yang disampaikan dalam program GASTIZI 1000 yaitu mengenai Stunting dan pentingnya gizi pada periode 1000 HPK. Subjek dipilih dengan metode total sampling yaitu seluruh kader posyandu di Desa Ngarap-arap yang bersedia mengikuti program GASTIZI 1000 HPK sebanyak 22 orang. Pengumpulan data karakteristik dan pengetahuan kader dilakukan dengan instrumen kuesioner pre test-post test. Data keterampilan kader dalam pemantauan status gizi stunting pada balita dikumpulkan dengan observasi dan wawancara terhadap subjek. Data diolah dengan software SPSS. Selanjutnya data dianalisis dengan uji univariat dan bivariat dengan related samples wilcoxon signed rank test. Hasil penelitian menunjukkan terdapatnya peningkatan pengetahuan kader setelah diberikan program GASTIZI $1000(p=0,001)$. Kesimpulan, terdapat peningkatan pengetahuan dan keterampilan kader mengenai stunting dan gizi 1000 HPK setelah mengikuti program GASTIZI.
\end{abstract}

Kata kunci: 1000 HPK, kapasitas kader posyandu, program GASTIZI 1000, stunting

\begin{abstract}
Posyandu cadres are the main actor of UKBM. "Prevention of Stunting with Nutritional Improvement on the 1000 days of life (GASTIZI 1000)" program has purpose to increase the posyandu cadre capasity at Ngarap-arap Village. This research aims to analyze the effectivity of GASTIZI 1000 program to improve the capacity of the posyandu cadres. This research uses a quasi experimental approach with one group pre test-post
\end{abstract}

test design. This research was conducted during July August 2018. Topics presenting in the GASTIZI 1000 program are about Stunting and the nutritional improvement at the 1000 days of life. Subjects are chosen by the total sampling method (All of posyandu cadre at Ngarap-arap village that are willingness to join the GASTIZI 1000 program), 22 people from 6 Hamlet in Ngarap-arap village. Characteristic and cadre knowledge were collected by pre test-post test questionnaire. Skill of cadre to monitor the nutritional status of children was collected by observation and interview. Data were compiled by SPSS software. Then analyzed by univariate and bivariate test with related samples wilcoxon signed rank test. The results showed the averaged score of cadres knowledge before the GASTIZI 1000 program is 51,8 and after program is 61,5. Bivariate test shows an increased in cadres knowledge after program ( $p=0,001)$. Conclusions, there was an increased in knowledge and skills of cadres about stunting and nutrition during 1000 days of life after following the program.

Keywords: GASTIZI 1000 program, stunting, 1000 days of life, capacity of posyandu cadres

\section{PENDAHULUAN}

Pos Pelayanan Terpadu yang dikelola dan diselenggarakan dari, oleh, untuk dan bersama masyarakat dalam pembangunan kesehatan merupakan ujung tombak dari pelayanan kesehatan dasar di masyarakat. ${ }^{1,2}$ Pos Pelayanan Terpadu (Posyandu) merupakan suatu bentuk dari Upaya Kesehatan Bersumberdaya Masyarakat yang ada di tiap wilayah desa. Pelaksana dari kegiatan Posyandu adalah kader posyandu yang berasal dari masyarakat setempat dan bekerja secara sukarela. ${ }^{2}$

Pos Pelayanan Terpadu memiliki peran dalam pemantauan status gizi dan tumbuh kembang balita melalui kegiatan

* Penulis untuk korespondensi: rachmapurwanti@fk.undip.ac.id 
penimbangan. Pos Pelayanan Terpadu juga memiliki peran dalam pendeteksian masalah gizi pada anak. Namun, dalam menjalankan perannya ada berbagai permasalahan yang sering dihadapi oleh Posyandu, diantaranya bahwa sebagian posyandu masih belum berfungsi dengan baik, sebagian besar kader belum mampu mandiri dan lebih dari separuh jumlah posyandu di Indonesia tidak memiliki peralatan memadai untuk pelaksanaan kegiatan. ${ }^{1,2}$ Kurang berfungsinya Posyandu dalam penjaringan dan deteksi masalah gizi seringkali disebabkan karena kemampuan kader yang masih rendah. ${ }^{3}$

Deteksi masalah gizi oleh kader Posyandu dilakukan melalui pengukuran antropometri Berat Badan (status gizi buruk, status gizi kurang, status gizi baik, dan status gizi lebih). Selain itu, pengukuran Tinggi Badan juga diperlukan untuk mengukur status gizi stunting yang ditandai dengan panjang/tinggi badan anak kurang dari anak seusianya $(\mathrm{PB} / \mathrm{U}$ atau $\mathrm{TB} / \mathrm{U}<-$ $3 \mathrm{SD}) .4,5$

Secara nasional, status gizi balita 0-59 bulan dengan indeks TB/U menunjukkan persentase balita pendek dan sangat pendek di Indonesia masih tinggi. Berdasarkan Hasil Riset Kesehatan Dasar Tahun 2018 diketahui persentase balita sangat pendek sebesar 11,5\% dan pendek sebesar 19,3\%. Padahal, target persentase balita pendek dan sangat pendek adalah kurang dari $20 \%$. Sedangkan pada balita 0-23 bulan persentase sangat pendek sebesar $7,1 \%$ dan pendek sebesar $14,6 \% .^{6}$

Terkait stunting, pemerintah Indonesia telah memprakarsai "Gerakan 1000 Hari Pertama Kehidupan (HPK)" 4,7 Seribu Hari Pertama Kehidupan (HPK) merupakan masa emas awal kehidupan yang berlangsung hanya 1000 hari yaitu masa kehamilan selama 270 hari hingga anak usia 2 tahun ( 730 hari). ${ }^{8}$ Seribu HPK bertujuan untuk percepatan perbaikan gizi pada masa balita untuk kehidupan di masa mendatang. Berbagai penelitian mengungkapkan bahwa intervensi pada 1000 HPK akan menunjang proses tumbuh kembang manusia sampai usia 2 tahun secara efektif, sedangkan kegagalan tumbuh kembang pada periode 1000 HPK akan berakibat pada daya tahan tubuh anak yang lemah, cenderung kurang aktivitas, pertumbuhan dan perkembangan yang kurang optimal, dan dapat berakibat pada gangguan metabolisme tubuh. ${ }^{4,9-11}$

Kecamatan Ngaringan merupakan salah satu kecamatan di Kabupaten Grobogan dengan kasus kematian neonatal, kematian bayi dan balita yang tinggi di Kabupaten Grobogan. Kasus gizi buruk pada balita juga masih terjadi di wilayah tersebut. ${ }^{12}$ Selain itu, meskipun saat ini pemerintah melalui Kementerian Kesehatan telah memiliki Aplikasi Pencatatan dan Pelaporan Gizi Berbasis Masyarakat atau yang disebut e-PPGBM. ${ }^{13}$ Aplikasi tersebut belum optimal terlaksana di Desa Ngarap-arap Kecamatan Ngaringan karena akses internet dan jaringan yang masih sangat kurang di wilayah timur Kabupaten Grobogan ini.

Hasil studi pendahuluan menunjukkan tidak adanya pengukuran tinggi badan di posyandu-posyandu, sehingga status gizi stunting pada balita tidak dapat terdeteksi sejak dini melalui program Posyandu. Kader Posyandu juga belum mengetahui istilah 1000 HPK dalam pencegahan dan penanggulangan stunting. Hal tersebut dikarenakan kurangnya pengetahuan, keterbatasan informasi, serta kurangnya sarana dan prasarana.

Hasil penelitian pada tahun 2011 di Tegal, Jawa Tengah menunjukkan bahwa ada perbedaan keterampilan kader posyandu dalam pengukuran antropometri sebelum dan sesudah pelatihan. ${ }^{14}$ Laporan lain di Banyumas menyebutkan bahwa pelatihan pemantauan status gizi balita pada kader posyandu terbukti telah dapat meningkatkan pengetahuan dan keterampilan kader tentang pemantauan status gizi. $^{15}$

Program GASTIZI 1000 dilaksanakan dengan sasaran utama yaitu kader posyandu. Namun, belum diketahui efektivitas dari program edukasi mengenai stunting dan pencegahannya dalam periode 1000 HPK yang diberikan kepada kader posyandu. Oleh karena itu, penelitian ini bertujuan untuk menganalisis efektivitas program pelatihan "Cegah Stunting dengan Perbaikan Gizi pada 1000 HPK (GASTIZI 1000)" dalam meningkatkan kapasitas kader posyandu di Desa Ngaraparap, Kecamatan Ngaringan, Kabupaten Grobogan. 


\section{METODE}

Penelitian ini dilaksanakan dengan pendekatan quasi experimental, dengan rancangan pre test-post test design. Subjek dalam penelitian ini adalah seluruh kader posyandu Desa Ngarap-arap, Kecamatan Ngaringan, Kabupaten Grobogan yang mengikuti program pelatihan GASTIZI 1000 yang diadakan oleh tim peneliti. Penelitian dilakukan pada bulan Juli - Agustus 2018. Subjek dipilih dengan metode total sampling yaitu seluruh kader posyandu yang bersedia mengikuti program GASTIZI 1000 sebanyak 22 orang yang berasal dari 6 dusun di wilayah desa Ngartap-arap.

Pengumpulan data karakteristik dan pengetahuan kader dilakukan dengan instrumen kuesioner pre test-post test. Data keterampilan kader dalam pemantauan status gizi stunting pada balita dikumpulkan dengan observasi dan wawancara terhadap subjek. Media yang digunakan adalah slide power point, poster, dan tikar pertumbuhan anak. Metode yang digunakan adalah ceramah, simulasi, dan diskusi kelompok. Pembagian kelompok didasarkan pada alamat tempat tinggal kader (per dusun).

Pengolahan data dilakukan dengan menggunakan software SPSS. Selanjutnya, dilakukan analisis data secara deskriptif yaitu analisis univariat (descriptive statistic) dan analisis bivariat. Analisis bivariat yang digunakan adalah uji non parametrik karena data tidak berdistribusi normal (Berdasarkan hasil uji normalitas dengan saphiro wilk nilai $\mathrm{p}$ $<0,05)$. Uji yang digunakan yaitu related samples wilcoxon signed rank test yang bertujuan untuk menguji apakah ada perbedaan/peningkatan skor pengetahuan sebelum dan setelah program GASTIZI 1000 dilaksanakan. Penyajian data hasil penelitian dibuat dalam bentuk tabel.

\section{HASIL DAN PEMBAHASAN}

Karakteristik subjek dalam penelitian ini meliputi jenis kelamin, umur, dan tempat tinggal (tabel 1). Seluruh subjek berjenis kelamin perempuan (100\%). Sebanyak 54,5\% subjek berumur lebih dari sama dengan 40 tahun dan $45,5 \%$ subjek lainnya berumur kurang dari 40 tahun. Tempat tinggal subjek penelitian berdasarkan asal dusun yaitu Dusun Kagok, Dusun Jetis, Dusun Tahunan, Dusun Brenggolo, Dusun Krajan I dan Krajan II.

Tabel 1. Karakteristik subjek penelitian

\begin{tabular}{lcc}
\hline \multirow{2}{*}{ Variabel } & \multicolumn{2}{c}{ Jumlah } \\
\cline { 2 - 3 } & $\mathrm{n}$ & $\%$ \\
\hline Umur & & \\
$<40$ tahun & 10 & 45,5 \\
$\quad$ 40 tahun & 12 & 54,5 \\
Alamat & & \\
$\quad$ Dusun Kagok & 3 & 13,6 \\
Dusun Jetis & 3 & 13,6 \\
Dusun Tahunan & 5 & 22,7 \\
Dusun Brenggolo & 3 & 13,6 \\
Dusun Krajan I & 4 & 18,2 \\
Dusun Krajan 2 & 4 & 18,2 \\
\hline \multicolumn{1}{c}{ Total } & 22 & 100 \\
\hline
\end{tabular}

Program GASTIZI 1000 yang dilakukan meliputi kegiatan edukasi Kader posyandu mengenai Stunting, pentingnya Gizi pada 1000 Hari Pertama Kehidupan (HPK), dan Training Pemantauan Status Gizi Stunting dengan tikar pertumbuhan. Hasil analisis univariat menunjukkan bahwa skor pengetahuan sebelum program GASTIZI 1000 dilaksanakan terendah adalah 33,3 dan skor tertingginya 80 .

Tabel 2. Skor pengetahuan kader posyandu

\begin{tabular}{lccccc}
\hline \multicolumn{1}{c}{ Pengetahuan } & n & Min. & Maks. & Rerata \pm Deviasi & Nilai p \\
\hline Sebelum program & 22 & 33,3 & 80,0 & $51,8 \pm 10,3$ & $0,001^{*}$ \\
Setelah program & 22 & 40,0 & 100,0 & $61,5 \pm 14,7$ & \\
*Beda signifikan berdasarkan uji Wilcoxon (beda sebelum - setelah program) &
\end{tabular}


Selanajutnya, setelah dilaksanakan program GASTIZI 1000 terjadi peningkatan pengetahuan subjek dengan skor terendah 40 dan skor tertingginya 100. Skor pengetahuan kader sebelum program rata-rata 51,8 dan setelah program rata-rata 61,5. Hasil uji Wilcoxon (tabel 2) menunjukkan adanya peningkatan pengetahuan dan keterampilan kader setelah diberikan program $(p=0,001)$. Hasil penelitian ini sesuai dengan penelitian terdahulu di Posyandu Mawar, Kedungbanteng, Banyumas yang melaporkan bahwa pelatihan pemantauan status gizi balita pada kader posyandu terbukti telah dapat meningkatkan pengetahuan dan keterampilan kader tentang pemantauan status gizi. $^{15}$

Hasil penelitian menunjukkan adanya peningkatan keterampilan kader posyandu dalam mengukur panjang badan dan tinggi badan balita serta menentukan status gizi stunting pada balita (hasil observasi pre-post). Akan tetapi, berdasarkan hasil wawancara, kader masih perlu dibimbing dalam penentuan status gizi secara cepat dan akurat.

Salah satu teori perubahan perilaku Stimulus-Organisme-Respon dikemukakan oleh Skinner (1938) dan Holland (1953), menyatakan bahwa proses perubahan perilaku pada hakikatnya sama dengan proses belajar yang terdiri dari stimulus (rangsang) dan diberikan pada organisme dapat diterima atau ditolak. Apabila stimulus tersebut tidak diterima atau ditolak (direspon) maka stimulus tersebut telah efektif mempengaruhi perhatian individu. Apabila stimulus telah mendapat perhatian dari organisme (diterima) maka ia mengerti stimulus ini dan dilanjutkan kepada proses berikutnya. Setelah itu organisme mengolah stimulus tersebut sehingga terjadi kesediaan untuk bertindak demi stimulus yang telah diterimanya (perubahan perilaku) ${ }^{16}$

Berkaitan dengan permasalahan kesehatan yang terjadi di Desa Ngarap-arap, perubahan perilaku sehat diharapkan dapat dimulai dari komitmen Kader Posyandu untuk memajukan UKBM. Adanya pelatihan untuk meningkatkan keterampilan yang bernilai merupakan faktor non finansial yang mendorong kader secara individu. ${ }^{17}$ Namun, pengetahuan dan keterampilan kader posyandu serta keterbatasan sarana dan prasarana untuk pemantauan tinggi badan juga menjadi kendala sehingga status gizi stunting pada balita tidak terdeteksi sejak dini. ${ }^{1}$ Pemahaman serta keterampilan yang kurang terutama tentang masalah gizi stunting dan periode kritis kehidupan manusia untuk pencegahan stunting yang dikenal dengan istilah 1000 HPK.

Kader posyandu merupakan anggota masyarakat yang bersedia, mampu, dan memiliki waktu menyelenggarakan kegiatan posyandu secara sukarela. Demikian pula kader posyandu di Desa Ngarap-arap, berasal dari anggota masyarakat setempat dan bersedia bekerja secara sukarela untuk Upaya Kesehatan Bersumberdaya Masyarakat yaitu posyandu. ${ }^{2}$ Kader posyandu memiliki tugas/peran yaitu: 1 . Menyiapkan tempat pelaksanaan, peralatan, sarana dan prasarana Posyandu, 2. Melaksanakan pendaftaran, 3. Melaksanakan penimbangan balita dan ibu hamil yang berkunjung ke Posyandu, 4. Mencatat hasil penimbangan di KMS atau buku KIA dan mengisi buku register Posyandu, 5. Modul Pelatihan Sistem Informasi Posyandu, 6. Melaksanakan penyuluhan kesehatan dan gizi sesuai dengan hasil penimbangan serta memberikan PMT, 7. Memberikan pelayanan kesehatan dan KB sesuai dengan kewenangannya, misalnya memberikan vitamin A, tablet besi, oralit, pil KB, kondom. Bila ada petugas kesehatan maka kegiatan kesehatan dilakukan bersama dengan petugas kesehatan, dan 8. Setelah selesai penimbangan bersama petugas kesehatan melengkapi pencatatan dan membahas hasil kegiatan serta tindak lanjut. ${ }^{1,2}$

Berdasarkan hasil analisis data, tidak ditemukan adanya perbedaan pengetahuan antara subjek yang berumur kurang dari 40 tahun maupun lebih dari 40 tahun. Umur mempunyai kaitan erat dengan tingkat kedewasaan serta kematangan dari seseorang. Kedewasaan ini meliputi kedewasaan teknis dan psikologis. Kedewasaan akan meningkat seiring dengan meningkatnya pengalaman seseorang. Hal ini menunjukkan bahwa kedewasaan akan 
meningkat seiring dengan bertambahnya umur sesorang karena pengalamannya juga akan meningkat. Selain itu, pada umur yang lebih muda biasanya seseorang akan lebih mudah dalam menerima stimulus karena belum turunnya kapasitas kognitif dan fungsi perkembangan lainnya. Namun, dalam penelitian ini perbedaan umur diketahui tidak berdampak signifikan terhadap pengetahuan. Hal tersebut dikarenakan perbedaan rentang umur dalam penelitian ini tidak terpaut jauh, dan rata-rata kader berumur antara 30-40 tahun sehingga perbedaan penerimaan stimulus antar masing-masing juga tidak berbeda signifikan.

Masing-masing wilayah dusun memiliki karakteristik yang tidak berbeda sehingga karakteristik kader posyandu dari keenam wilayah dusun ini juga tidak berbeda signifikan.

Program GASTIZI 1000 dilakukan meliputi kegiatan: 1) Edukasi Kader posyandu mengenai Stunting; 2) Edukasi Kader posyandu mengenai Pentingnya Gizi pada 1000 Hari Pertama Kehidupan (HPK); dan 3) Training Pemantauan Status Gizi Stunting dengan tikar pertumbuhan. Edukasi memuat beberapa informasi kunci yaitu ASI eksklusif diberikan selama 6 bulan, IMD, pengenalan bentuk-bentuk MP-ASI, penyebab dan dampak dari stunting, pengukuran panjang badan dan tinggi badan sebagai indikator stunting, dan masa 1000 Hari Pertama Kelahiran (HPK).

Berdasarkan hasil analisis univariat diketahui bahwa skor pengetahuan sebelum program GASTIZI 1000 dilaksanakan rata-rata 51,8 dan setelah program rata-rata 61,5. Nilai rata-rata skor pengetahuan meningkat sebesar 0,7 point. Selain itu terjadi pula peningkatan nilai minimum dan maksimum setelah program dilaksanakan dari 33,3 - 80,0 menjadi 40,0 100,0 .

Rendahnya pengetahuan kader sebelum dilakukannya program sesuai hasil penelitian terdahulu yang melaporkan bahwa kader secara umum memiliki pengetahuan kurang dan tidak pernah mengikuti pelatihan. Padahal, tingkat partisipasi masyarakat ke posyandu masih tergantung pada keaktifan kader dalam mengingatkan tentang hari buka posyandu. ${ }^{18}$ Kader selama ini juga diharapkan dapat menjalankan peranannya dengan baik, tetapi di sisi lain mereka tidak pernah dipersyaratkan untuk memiliki pengetahuan dan kemampuan yang memadai di bidang gizi dan kesehatan untuk menjalankan tugasnya. ${ }^{17,19}$

Rata-rata kader juga memiliki tingkat pendidikan menengah ke bawah. Padahal, pendidikan, pengetahuan, dan motivasi terbukti memiliki pengaruh terhadap peran kader dalam upaya perbaikan gizi balita. ${ }^{20}$ Oleh karena itu, program yang ditujukan untuk meningkatkan pengetahuan dan keterampilan akan sangat bermanfaat bagi kader.

Program GASTIZI 1000 dalam penelitian ini berdampak terhadap peningkatan pengetahuan kader yang ditunjukkan dari hasil uji statistik wilcoxon bahwa ada peningkatan pengetahuan dan keterampilan kader setelah mengikuti program GASTIZI $1000(\mathrm{p}=0,001)$. Adanya peningkatan pengetahuan meliputi pengetahuan tentang ASI eksklusif, IMD, pengenalan bentuk-bentuk MP-ASI, penyebab stunting, dampak dari stunting, pengukuran panjang badan dan tinggi badan sebagai indikator stunting, dan masa 1000 Hari Pertama Kelahiran (HPK).

Hasil penelitian ini sesuai dengan laporan terdahulu di Posyandu Mawar, Kedungbanteng, Banyumas yang melaporkan bahwa pelatihan pemantauan status gizi balita pada kader posyandu terbukti telah dapat meningkatkan pengetahuan dan keterampilan kader. ${ }^{15}$ Hasil penelitian ini juga sesuai dengan penelitian lain bahwa ada pengaruh pelatihan terhadap pengetahuan dan tindakan kader dalam menilai dan memantau pertumbuhan balita. ${ }^{21}$

Kader diharapkan dapat menjembatani antara petugas / ahli kesehatan dengan masyarakat serta membantu masyarakat mengidentifikasi dan menghadapi / menjawab kebutuhan kesehatan mereka sendiri. Kader dapat membantu mobilisasi sumber daya masyarakat, mengadvokasi masyarakat serta membangun kemampuan lokal. ${ }^{17}$ Dengan adanya peningkatan pengetahuan kader tentang stunting dan 1000 HPK melalui program GASTIZI 1000 ini maka penyampaian informasi kepada masyarakat luas juga akan lebih baik dan lebih cepat.

Keterampilan merupakan hasil dari pelatihan yang dilakukan secara berulang, 
berupa meningkatnya kemampuan teknis dari seseorang. Peningkatan keterampilan dapat dilihat dari peningkatan/progresivitas dari kemampuan seseorang setelah mengikuti kegiatan'aktivitas tertentu. Keterampilan dalam penelitian ini dilihat dengan observasi dan wawancara langsung pada subjek penelitian yang menunjukkan adanya peningkatan keterampilan kader posyandu dalam mengukur panjang badan dan tinggi badan balita serta menentukan status gizi stunting pada balita (hasil observasi). Keterampilan yang baik dalam pemantauan Tinggi Badan balita termasuk dalam faktor non finansial yang dapat mendorong kinerja kader posyandu. ${ }^{17,22}$

Keterampilan dalam penelitian ini dilihat secara kualitatif karena berdasarkan hasil observasi dan wawancara. Akan tetapi, berdasarkan hasil wawancara, kader masih perlu dibimbing dalam penentuan status gizi secara cepat dan akurat. Cara menentukan status gizi stunting pada balita menentukan kejelian dan ketelitian dan perlu latihan serta pembiasaan sehingga diharapkan dengan seringnya keterampilan tersebut diaplikasikan maka kader akan semakin mahir. Namun, kader masih perlu dibimbing oleh tenaga kesehatan (Bidan/Tenaga kesehatan lainnya dari Puskesmas).

Selain pengetahuan dan juga motivasi, keterampilan kader posyandu merupakan salah satu kunci keberhasilan sistem pelayanan di Posyandu. Keterampilan kader posyandu dalam melaksanakan kegiatan posyandu akan meningkatkan kepercayaan dan respon positif dari ibu balita yang datang ke posyandu, selanjutnya akan berdampak pada meningkatnya cakupan D/S balita di posyandu. Keterampilan dari kader posyandu juga akan meningkatkan kepercayaan diri dari kader serta membantu kader dalam memecahkan berbagai permasalahan yang dihadapi dalam melaksanakan kegiatan posyandu.

\section{KESIMPULAN}

Program GASTIZI 1000 yang dilaksanakan di Desa Ngarap-arap Kabupaten Grobogan secara keseluruhan dapat meningkatkan pengetahuan dan keterampilan kader posyandu mengenai pencegahan stunting dengan perbaikan gizi pada periode 1000 Hari Pertama Kehidupan. Pengetahuan kader yang masih kurang dan perlu untuk ditingkatkan adalah mengenai penekanan masa growth spurt pada anak, bentuk makanan untuk pengenalan MP-ASI, dampak jangka panjang stunting, stunting tidak terjadi karena gen orang tua, serta keterampilan kader dalam menentukan status gizi anak (penentuan status gizi stunting masih perlu dilatih dan didampingi).

Saran, diperlukan adanya penelitian lanjutan yang menggunakan pembanding (kelompok kontrol) agar dampak dari program dapat lebih terukur.

\section{KEPUSTAKAAN}

1. Departemen Kesehatan RI. Buku Pedoman Umum Pengelolaan Posyandu. Jakarta: Departemen Kesehatan RI bekerjasama dengan Kelompok Kerja Operasional Posyandu; 2006.

2. Kementerian Kesehatan RI. Buku Panduan Kader Posyandu Direktorat Bina Gizi Menuju Keluarga Sadar Gizi.; 2011.

3. Sukiarko E. Pengaruh Pelatihan dengan Metode Belajar Berdasarkan Masalah dalam Kegiatan Kader Gizi Posyandu: Studi di Kecamatan Tempuran Kabupaten Magelang. Jurnal Media Medika Indonesia. 2007;3:103147.

4. Tim Nasional Percepatan Penanggulangan Kemiskinan. 100 Kabupaten/Kota Prioritas Untuk Intervensi Anak Kerdil (Stunting). 1st ed. Jakarta; 2017.

5. Kemenkes RI. Keputusan Menteri Kesehatan republik Inodnesia Nomor 1995/ Menkes/ SK/ XII/ 2010. Standar Antropometri Penilaian status Gizi. Kementerian Kesehatan RI. 2010.

6. Kementerian Kesehatan. Riset Kesehatan Dasar 2018. 2018.

7. Kementerian Kesejahteraan Rakyat. Pedoman Perencanaan Program Gerakan Nasional Percepatan Perbaikan Gizi Dalam Rangka Seribu Hari Pertama Kehidupan (Gerakan 1000 HPK).; 2013.

8. Kementerian kesehatan. Seribu hari untuk negeri. Panduan Gerakan Nasional Sadar Gizi Menuju Manusia Indonesia Tetap Prima. :124.

Jurnal AcTion, Volume 4, Nomor 1, Mei 2019 
9. Grantham-McGregor S, Cheung YB, Cueto S, Glewwe P, Richter L, Strupp B. Developmental potential in the first 5 years for children in developing countries. Lancet. 2007;369(9555):60-70. doi:10.1016/S01406736(07)60032-4.

10. Grantham-McGregor S, Baker-Henningham $\mathrm{H}$. Review of the evidence linking protein and energy to mental development. Public Health Nutrition. 2005;8(7A):1191-1201.11.

Lewit EM, Kerrebrock N. Populationbased growth stunting. The Future of Children. Children and Poverty. 2019;7(2):149-156.

12. Dinas Kesehatan Kabupaten Grobogan. Profil Kesehatan Kabupaten Grobogan. Grobogan; 2016.

13. Direktorat Gizi Masyarakat Direktorat Jenderal Kesehatan Masyarakat. Buku Panduan Pencatatan Dan Pelaporan Gizi Berbasis Masyarakat (e-PPBGM). Sistem Informasi Gizi Terpadu. Jakarta: Kementerian Kesehatan RI; 2017.

14. M HF, Mardiana. Keterampilan kader posyandu sebelum dan sesudah pelatihan. Jurnal Kesehatan Masyarakat. 2011;7(1):25-31.

15. Zaki I, Farida, Sari HP. Peningkatan kapasitas kader posyandu melalui pelatihan pemantauan status gizi balita. Jurnal pengabdian kepada masyarakat. 2018;3(2):177-187.

16. Notoatmodjo S. Promosi Kesehatan Dan Ilmu Perilaku. Jakarta: Rineka Cipta; 2007.
17. Iswarawanti DN. Kader Posyandu: Peranan dan Tantangan pemberdayaannya dalam usaha peningkatan gizi anak di Indonesia. Jurnal Manajemen Pelayanan Kesehatan. 2010;13(04):169-173.

18. Akbar MA, Kandarina BI, Gunawan IMA. Studi ketidakaktifan kader posyandu di Wilayah Kerja Puskesmas Paramasan, Banjar, Kalimantan Selatan. Jurnal Gizi dan Dietetik Indonesia. 2015;3(1):60-67.

19. Hardiyanti R, Jus'at I, Angkasa D. Hubungan lama kerja menjadi kader, pengetahuan, pendidikan, pelatihan dengan presisi dan akurasi hasil penimbangan berat badan balita oleh kader Posyandu. AcTion: Aceh Nutrition Journal. 2018;3(1):74-81. http://dx.doi.org/10.30867/action.v3i1.10 2

20. Kartika, Mufida N, Karmila, Marlina. Factors Affecting Kader Role In Achievement Nutrition Improvement In Toddlers in. Jurnal Kesehatan Global. 2018;1(2):45-51.

21. Lubis Z, Syahri IM. Pengetahuan dan Tindakan Kader Posyandu dalam Pemantauan Pertumbuhan Anak Balita. Jurnal Kesehatan Masyarakat. 2015;11(1):65-73.

22. AL-Rahmad AH. Peningkatan Ketepatan Kader Melalui Modul Pendamping KMS dalam Menginterpretasikan Hasil Penimbangan Balita. Jukema (Jurnal Kesehatan Masyarakat Aceh). 2016;2(2). 